\title{
Chemical composition, cytotoxicity and anti-mycobacterium activities of Clausena anisata essential oils
}

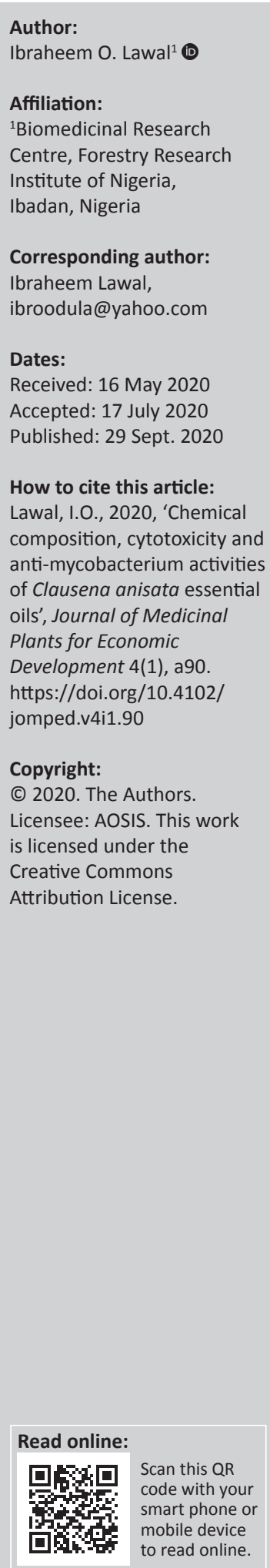

Background: Clausena anisata (Willd) Hook has demonstrated several medicinal properties against certain bacterial infections, including tuberculosis. However, scientific validation is imperative to verify its folkloric usage against tuberculosis.

Aim: This study aimed at determining the chemical composition, toxicity and anti-tubercular potentials of the oils extracted from this plant.

Setting: Plant material collection, essential oils extraction and antimycobacterial activity were performed at the University of Fort Hare, Alice, South Africa. This article and selected technical aspect was constructed at the Biomedicinal Research Centre, Forestry Research Institute of Nigeria.

Methods: Comparative chemical composition of hydrodistilled (HD) and solvent-free microwaved essential (SFME) oils from $C$. anisata was analysed by gas chromatography coupled with mass spectroscopy (GC-MS). In vitro minimum inhibitory concentration (MIC) assay was also carried out on the oils against a strain of Mycobacterium tuberculosis. The cytotoxicity assay of the oils was also assessed by using human dermal fibroplast (MRHF) cell lines.

Results: Gas chromatography-mass spectroscopy analysis of the essential oils revealed 51 distinct compounds with methyl eugenol and estragole in abundance. $\mathrm{The}^{\mathrm{IC}} \mathrm{C}_{50}$ of volatile oils from SFME and HD methods against the MRHF cell line were $1216 \mu \mathrm{g} / \mathrm{mL}$ and $383 \mu \mathrm{g} / \mathrm{mL}$, respectively. On the other hand, both oils and ethambutol (standard drug) showed no activity against the strain of $M$. tuberculosis, but rifampicin supressed the growth of the organism at $0.25 \mu \mathrm{g} / \mathrm{mL}$.

Conclusion: This study showed that $C$. anisata is safe for consumption, and further studies of combinative potent but non-toxic oils engaging hydrodistillation method are strongly recommended for enhanced effect against $M$. tuberculosis.

Keywords: solvent-free microwave extraction; tuberculosis; hydrodistillation; medicinal plant; clausena specie; volatile oil.

\section{Introduction}

Mycobacterium tuberculosis is the causative pathogen of tuberculosis (TB) that most often affects the lungs (WHO 2018). Tuberculosis remains a significant public health issue in low- and middle-income countries, and as reported by World Health Organization (WHO 2017) it is the leading cause of deaths as a single infectious disease, ranking above human immunodeficiency virus (HIV) and acquired immune deficiency syndrome (AIDS). Tuberculosis is responsible for approximately 2 million deaths annually (Ibekwe \& Ameh 2015). The WHO (2017) reported $6.3 \mathrm{~m}$ new cases of TB amongst HIV-negative people in 2016. According to WHO (2018), about one-third of the world's population has latent TB, which means people have been infected by $M$. tuberculosis but are not yet ill with the disease and cannot transmit it to another person. The WHO African region accounted for $25 \%$ of the total number of incident cases globally. In the past two decades, the WHO has listed Nigeria as one of the countries with a high burden of TB (WHO 2015). It has also been estimated that about $80 \%$ of South African population is infected with TB, with $88 \%$ highest prevalence of latent TB amongst the age group of 30-39 years living in the rural settlements (TB Statistics 2015).

The primary treatment for M. tuberculosis disease is chemotherapy (CDC 2016). The recent increase in the widespread existence of extensively drug-resistant tuberculosis (XDR-TB) especially in the developing nations emphasises the need for the development of new drugs to treat this infection. Such new anti-tubercular agents should have novel modes of action 
and full activity against $M$. tuberculosis (WHO 2012). And now, during the time of coronavirus disease 2019 (COVID-19) outbreak, WHO is imploring governments to ensure TB services are maintained. Tuberculosis, being a bacterial disease, shares similar patterns of respiratory symptoms with COVID-19 (a viral disease), and a bit of imitation from the way it incubates in asymptomatic infected persons to the way it sickens symptomatic persons. However, a COVID-19-infected person who is yet asymptomatic may be able to transmit the infection (CDC 2020) as different from the case of TB.

For the fact that chemical agents are engaged in the primary treatment of TB, rifampicin, which is a nucleic acid synthesis inhibitor and believed to inhibit bacterial deoxyribonucleic acid-dependent ribonucleic acid polymerase, has been used as a first-line drug in combination with other therapies for the treatment of TB infections (Shehzad et al. 2013). Ethambutol (EMB), a cell wall inhibitor, is another first-line drug used in combination with isoniazid, rifampicin and pyrazinamide for preventing the emergence of drug-resistant mycobacterium. This drug interferes with the cell wall of $M$. tuberculosis through a synthetic mechanism, thereby inhibiting arabinosyl-transferase (embB), an enzyme involved in cell wall biosynthesis (Teleuti et al. 1997). However, new chemical compounds that might play an important role in the chemotherapy of TB are sourced from natural products and/or their semi-synthetic derivatives (Payan et al. 2009). Therefore, it is important to search for new anti-tubercular agents, preferably those that can be readily produced from medicinal plants.

Clausena anisata (Willd) Hook. F. ex Benth is a small tree about $10 \mathrm{~m}$ in height belonging to the family Rutaceae, and known by local name 'olmaa'ii' in Ethiopia (Afanoromo language), in South Africa as 'Isifudu' (Zulu) and 'umNukelambiba' (Swazi). It is also known as 'Perdepis' (Afrikaans) because the crushed leaves have a characteristic unpleasant horse's urine smell. Clausena anisata is abundant in forests and forest margins, riverine thickets and bushveld, from Western Cape up the eastern coast of KwaZulu-Natal, Mpumalanga, eastern Zimbabwe, Mozambique, northwards to Ethiopia and Sudan and westwards to Sierra Leone where it plays a major role in the ecosystem as regulating and supporting services (Van Wyk \& Gericke 2000; Van Wyk, Van Oudtshoorn \& Gericke 2002). The main stem is smooth, grey to light brown, and the leaves alternate with each leaf having 4-10 pairs of leaflets. The flowers have white petals with numerous yellow stamens. The fruits are berries, initially green, then reddish-black when fully ripe, providing a source of nourishment to many bird and insect species. The wood is yellow, hard and strong and is used for hut-building and the making of knobkerries (Van Wyk et al. 2002).

South African traditional healers have been engaging in the use of $C$. anisata leaves, bark and root to treat a variety of ailments including cough and TB (Van Wyk \& Griecke 2000; Van Wyk et al. 2002). The various morphological parts of the plant have been identified to be effective remedies against worm infections, respiratory ailments, heart disorders, hypertension, malaria fever, rheumatism, insanity, convulsion and other inflammatory conditions (Hamza, Van den BoutVan den Beukel \& Matee 2006; Hutchings et al. 1996). In many African countries, especially South Africa, many people still use phytomedicine as an alternative or to supplement western drugs (Grierson \& Afolayan 1999; Lawal, Grierson \& Afolayan 2014). The inhibitory properties of medicinal plants against M. tuberculosis have been reported by many researchers both in South Africa and in other countries (Payan et al. 2009), but there is a dearth of information on the inhibitory properties of C. anisata, which is popular ethnomedicinally for the treatment of TB, especially in South Africa.

The aim of this study, therefore, was to evaluate $C$. anisata essential oils for their antimycobacterium and cytotoxicity activities.

\section{Materials and methods Plant collection and identificaton}

Identification of the collected plant specimens was done by Prof. D.S. Grierson of the Department of Botany at the University of Fort Hare, South Africa. Voucher specimens with the voucher number (Lawmed 01) were deposited in the Giffen Herbarium of the University of Fort Hare.

\section{Solvent-free microwave extraction}

The solvent-free microwave extraction was achieved by using the Milestone Dry Distillation (DIST) (2004) apparatus. The multimode reactor has a twin magnetron (2800 watts [W], 2450 megahertz $[\mathrm{MHz}]$ ) with a maximum delivered power of $500 \mathrm{~W}$ in $5 \mathrm{~W}$ increments. Rotating microwave diffusers ensure homogeneous microwave distribution throughout the plasmacoated polytetrafluoroethylene (PTFE) cavity. The attached infrared radiation (IR) sensor was used to regulate the temperature. Constant conditions of temperature and water were guaranteed by the reflux of condensed water, which was achieved by a circulating cooling system at $5{ }^{\circ} \mathrm{C}$. An amount of $250 \mathrm{~g}$ of $\mathrm{C}$. anisata fresh leaves was placed into the reactor without addition of water or any solvent. The exhaustive extraction of the essential oil was obtained in $30 \mathrm{~min}$.

\section{Hydrodistillation}

In brief, $250 \mathrm{~g}$ of the fresh leaves were hydrodistilled (HD) for $3 \mathrm{~h}$ in an all-glass Clevenger apparatus in accordance with the description of the British Pharmacopoeia (1980). The heat was supplied to the heating mantle $\left(100^{\circ} \mathrm{C}\right)$, and the essential oil was extracted with $5 \mathrm{~L}$ of distilled water for $3 \mathrm{~h}$. The essential oil was collected and analysed without delay.

\section{Gas chromatography-mass spectroscopy analysis}

The chemical composition profiling of essential oils extracted through hydrodistillation (HD) and solvent-free microwaved essential (SFME) was achieved through gas chromatography- 
mass spectroscopy (GC-MS) analysis. This was carried out by using an Agilent (6890N) GC with chlortetracycline (CTC) Combi Pal Autosampler and Agilent (5975B) MS. Identification of the chemical components of the essential oils was accomplished by corresponding their mass spectra and retention indices with those of the Wiley 275 library (Okoh, Sadimenko \& Afolayan 2010; Omoruyi, Anthony \& Bradley 2014). The column type was Zebron (ZB) 274305, Semi volatiles $(30 \mathrm{~m}, 0.25 \mathrm{~mm}$ identification (ID), $0.25 \mu \mathrm{m}$ film thicknesses). The spectrograms of each identified compound were determined by the integration of the peak areas. The initial temperature was $280{ }^{\circ} \mathrm{C}$; pressure, $96.9 \mathrm{kN} / \mathrm{m}^{2}$; split ratio, 20:1; split flow, $19 / 9 \mathrm{~mL} / \mathrm{min}$; total flow, $23.7 \mathrm{~mL} / \mathrm{min}$; column flow, $1 \mathrm{~mL} / \mathrm{min}$; nominal initial pressure, $52.4 \mathrm{kN} / \mathrm{m}^{2}$; average velocity, $36 \mathrm{~cm} / \mathrm{s}$; gas type, Helium; MS mode, EI+; scanning mass range, $35 \mathrm{~m} / \mathrm{z}-600$ mass per charge number $(\mathrm{m} / \mathrm{z})$; solvent delay, $4.65 \mathrm{~min}$.

\section{Cytotoxicity assays}

\section{Cell culture conditions}

The adherent human dermal fibroblast (MRHF) cell line was routinely maintained in 10-cm culture dishes without antibiotics in Dulbecco's Modified Eagle Medium (DMEM) cell culture medium containing $4500 \mathrm{mg} / \mathrm{L}$ glucose, $4 \mathrm{mM}$ glutamine and sodium pyruvate (HyClone Laboratories, Inc., South Logan, Utah, United States), and 10\% foetal bovine serum (Gibco, Grand Island, New York, United States) in a humidified incubator and $5 \% \mathrm{CO}_{2}$ at $37^{\circ} \mathrm{C}$.

\section{Sample preparation}

Volatile oils extracted by using SFME and hydrodistillation methods were reconstituted in absolute ethanol as stock concentrations of $100 \mathrm{mg} / \mathrm{mL}$. Stock concentrations were stored at $-80{ }^{\circ} \mathrm{C}$ to prevent evaporation.

\section{Screening protocol}

Working concentrations $(500 \mu \mathrm{g} / \mathrm{mL})$ of the volatile oils were prepared from the stock concentrations in complete medium, which were serially diluted to concentrations between $1.95 \mu \mathrm{g} / \mathrm{mL}$ and $250 \mu \mathrm{g} / \mathrm{mL}$. Absolute ethanol $(0.5 \%$, volume per volume $[\mathrm{v} / \mathrm{v}])$ and melphalan $(50 \mu \mathrm{M}$ and $100 \mu \mathrm{M}$ ) were used as negative (vehicle) and positive controls, respectively.

Cells were seeded into a 96-well microtitre plate at a cell density of 30000 cells $/ \mathrm{mL}$, by using $200 \mu \mathrm{L}$ of the cell suspension per well (6000 cells/well). The microtitre plate was incubated for $24 \mathrm{~h}$ in a humidified incubator and $5 \% \mathrm{CO}_{2}$ at $37^{\circ} \mathrm{C}$, prior to the addition of the volatile oils. Spent medium was aspirated from the wells and replaced with the appropriate treatment. The plate was returned to the incubator, and the cells were incubated for $24 \mathrm{~h}$.

\section{Methylthiazol tetrazolium assay}

After $24 \mathrm{~h}$, treatments were removed via aspiration, $200 \mu \mathrm{L}$ MTT $0.5 \mathrm{mg} / \mathrm{mL}$ (Holst-Hansen \& Brünner 1998) dissolved in complete medium, added to each well and incubated for $3 \mathrm{~h}$ at $37^{\circ} \mathrm{C}$. Methylthiazol tetrazolium (MTT) was removed via aspiration, $100 \mu \mathrm{L}$ DMSO was added to each well to dissolve the formazan crystals and the absorbance was read at 540 nanometer (nm) by using a BioTek ${ }^{\circledR}$ PowerWave XS spectrophotometer.

\section{Data analysis}

Cell viability was determined by using four replicate wells for each concentration. Vehicle control wells were considered to have $100 \%$ cell viability (i.e. the mean OD of the untreated wells $=100 \%$ viability). Cell viability in test wells was calculated relative to the vehicle control and expressed as a percentage. $\mathrm{IC}_{50}$ was calculated by using $\mathrm{ED}_{50} \mathrm{~V} 10$ add-in on Excel.

\section{Antimycobacterium assays}

\section{Microorganism, growth conditions and media}

The M. tuberculosis strain H37 was obtained from the National Health Laboratory Services (NHLS), Port Elizabeth, South Africa. Mycobacterium tuberculosis was grown in a culture broth containing Difco ${ }^{\mathrm{TM}}$ Middlebrook $7 \mathrm{H} 9$ broth (BD), glycerol, Tween ${ }^{\circledR} 80$ and Middlebrook albumin-dextrosecatalase (ADC) growth supplement (Sigma) at $37^{\circ} \mathrm{C}$.

\section{Control antibiotics}

Rifampicin and EMB dihydrochloride (Sigma) were used as antibiotic positive controls against $M$. tuberculosis. Rifampicin and EMB were dissolved in sterile water at stock concentrations of $1 \mathrm{mg} / \mathrm{mL}$ and $2 \mathrm{mg} / \mathrm{mL}$, respectively. From pre-screening, working concentrations of $16 \mu \mathrm{g} / \mathrm{mL}$ and $128 \mu \mathrm{g} / \mathrm{mL}$ were prepared for rifampicin and $\mathrm{EMB}$, respectively, in culture broth (without Tween $\left.{ }^{8} 80\right)$ and filter sterilised $(0.2 \mu \mathrm{M}$ filter).

\section{Sample preparation}

Working concentrations of $500 \mu \mathrm{g} / \mathrm{mL}$ were prepared in culture broth (without Tween $₫ 80$ ) and filter sterilised $(0.2 \mu \mathrm{M}$ filter) from the reconstituted stock concentration of both volatile oils obtained from solvent-free microwave extraction and hydrodistillation.

\section{Microbroth dilution method}

The assay was performed as described by Franzblau et al. (1998) with modifications. The outer perimeter wells of clear 96-well plates were filled with sterile water to minimise evaporation of medium in experimental wells during incubation. In brief, culture broth $(100 \mu \mathrm{L})$ was added to all experimental wells (i.e. volatile oils and antibiotics) except to the highest volatile oil and antibiotic concentration wells to which $200 \mu \mathrm{L}$ of the working concentrations was added. Serial dilutions (1:2) were prepared for the volatile oils $(3.9 \mu \mathrm{g} / \mathrm{mL}-250 \mu \mathrm{g} / \mathrm{mL})$, rifampicin $(0.0625 \mu \mathrm{g} / \mathrm{mL}-8 \mu \mathrm{g} / \mathrm{mL})$ and $\mathrm{EMB}$ $(0.25 \mu \mathrm{g} / \mathrm{mL}-32 \mu \mathrm{g} / \mathrm{mL})$. The $M$. tuberculosis culture was assessed and adjusted to a 0.5 McFarland standard (absorbance at $600 \mathrm{~nm}=0.08-0.1$; equivalent to $\sim 1.5 \times 108$ cells $/ \mathrm{mL}$ ) and $100 \mu \mathrm{L}$ added to each test well. 
The following controls were prepared:

- Antibiotic/medium control $(100 \mu \mathrm{L}$ medium $+100 \mu \mathrm{L}$ of highest antibiotic concentration);

- Volatile oil/medium control (100 $\mu \mathrm{L}$ medium $+100 \mu \mathrm{L}$ of highest volatile oil concentration);

- $0.5 \%$ absolute ethanol control $(100 \mu \mathrm{L}$ medium $+100 \mu \mathrm{L}$ $1 \%$ absolute ethanol); and

- Micro-organism growth control $(100 \mu \mathrm{L}$ medium $+100 \mu \mathrm{L}$ M. tuberculosis inoculum).

Plates were sealed with microplate sealing tape and incubated at $37^{\circ} \mathrm{C}$ for 7 days.

\section{CellTiter-Blue cell viability assay}

After treatment, $40 \mu \mathrm{L}$ of CellTiter-Blue ${ }^{\circledR}$ Reagent (Promega) and $12.5 \mu \mathrm{L} \mathrm{20 \%}$ Tween ${ }^{\circledR} 80$ were added to each well. Wells were observed for colour change, where a blue colour represents no growth (non-viable cells) and a pink colour represents growth (viable cells). After $6 \mathrm{~h}, \mathrm{M}$. tuberculosis cells were killed by adding 35\% formaldehyde to reach a final concentration of $10 \%$ in each well. This was done to eliminate the biosafety hazard of $M$. tuberculosis aerosols. The absorbance was read at $570 \mathrm{~nm}$ and at a reference wavelength of $600 \mathrm{~nm}$ by using a BioTek $\AA$ PowerWave XS spectrophotometer.

\section{Ethical consideration}

Ethical clearance was not needed for the study.

\section{Results \\ Chemical composition}

The essential oils of $C$. anisata obtained by HD and solventfree extraction (SFME) process are shown in Table 1. The results obtained by GC-MS analyses of the oils from both extraction methods showed a total of 51 distinct molecular compounds; 36 and 22 chemical compounds were identified in the essential oils extracted through HD and SFME respectively whilst oils of both extraction methods shared 8 similar compounds namely, $\alpha$-pinene; limonene; 1, 8- cineole; bornyl acetate; methyl eugenol; cismethyl isoeugenol; germacrene-D; and (+) spathulenol. A good number of chemical compounds with substantial amounts were found in the essential oils of C. anisata, and higher percentage composition of these compounds above $1 \%$ in HD essential oils, which are shown in Figure 1, are methyl eugenol, 36.04\%; 4-allyl anisole (estragole), 26.43\%; Limonene, $10.99 \%$; $\beta$-myrcene, $8.28 \%$; germacrene- $\mathrm{D}, 2.08 \%$; trans-methyl isoeugenol, $1.97 \%$; and $\beta$-cubebene, $1.15 \%$; whilst in SFME are methyl eugenol, $76.60 \%$ and methyl charicol (estragole), $14.48 \%$. Methyl eugenol and estragole were the most abundant compounds present in both oils.

Results of cytotoxic activity of $C$. anisata essential oils at the concentrations range of $1.95 \mu \mathrm{g} / \mathrm{mL}-500 \mu \mathrm{g} / \mathrm{mL}$ are graphically shown in Figure 2. The cytotoxic activity of C. anisata essential oils on MRHF cell line was evaluated by using the MTT assay. The essential oils from both extraction methods showed significant effect on MRHF cells at $250 \mu \mathrm{g} / \mathrm{mL}$ and $500 \mu \mathrm{g} / \mathrm{mL}$. The highest cytotoxic activity of the oils was found at $500 \mu \mathrm{g} / \mathrm{mL}$ concentration as Figure 2 depicts the \% cell viability of SFME and HD reduced to approximately $81 \%$ and $39 \%$, respectively. The cytotoxic effects of volatile oil obtained by solvent-free microwave extraction against the MRHF cell line between $1.95 \mu \mathrm{g} / \mathrm{mL}$ and $125 \mu \mathrm{g} / \mathrm{mL}$ showed approximately $100 \%$. It was observed that the percentage of cell viability shown in Figure 2 decreased with increasing concentration of volatile oil from concentrations above $125 \mu \mathrm{g} / \mathrm{mL}$.

There is a significant difference only between HD and SFME at $7.81 \mu \mathrm{g} / \mathrm{mL}, 500 \mu \mathrm{g} / \mathrm{mL}$, and positive control at $100 \mu \mathrm{M}$ Melphalan.

\section{Antimycobacterial activity}

The results from the antimycobacterial assay are presented in Plates A.1 and A.2 for both oils and standard drugs, respectively (Appendix 1). Wells A1-12 and H1-12 contain sterile water. The 96-well microtitre plate showed all the concentrations $(3.9,7.8,15.6,31.3,62.5,125,250 \mu \mathrm{g} / \mathrm{mL}$ in wells labelled 5 to 11) for both solvent-free microwave extraction volatile oil (represented in wells B, C, D), and HD volatile oil (represented in wells E, F, G). The mycobacterial growth in these wells formed as pink colour indicating growth or viable cells, except in well 2 (control 1), which contained $100 \mu \mathrm{L}$ medium and $100 \mu \mathrm{L}$ of $500 \mu \mathrm{g} / \mathrm{mL}$ volatile oil with no M. tuberculosis, are observed in the Plate A.1. As none of the wells treated with the essential oils is noted to inhibit $M$. tuberculosis growth, this study observes a minimum inhibitory concentration (MIC) $>250 \mu \mathrm{g} / \mathrm{mL}$, which is similar to the case of one of the standard drugs, EMB (represented in wells E, F, G), observation of concentration between $0.063 \mu \mathrm{g} / \mathrm{mL}$ and $8 \mu \mathrm{g} / \mathrm{mL}$. In contrast, the concentrations $(0.063 \mu \mathrm{g} / \mathrm{mL}, 0.125 \mu \mathrm{g} / \mathrm{mL}, 0.25 \mu \mathrm{g} / \mathrm{mL}, 0.5 \mu \mathrm{g} / \mathrm{mL}$, $1 \mu \mathrm{g} / \mathrm{mL}, 2 \mu \mathrm{g} / \mathrm{mL}, 4 \mu \mathrm{g} / \mathrm{mL}, 8 \mu \mathrm{g} / \mathrm{mL}$ contained in wells 4-11 of Plate A.2) available for the other standard drug, Rifampicin, showed observable and significant colour change from pink to blue between $0.25 \mu \mathrm{g} / \mathrm{mL}$ and $8 \mu \mathrm{g} / \mathrm{mL}$, as blue colour indicates no growth or non-viable cells of M. tuberculosis. This study records antimycobacterial activity at $\mathrm{MIC}=0.25 \mu \mathrm{g} / \mathrm{mL}$ for rifampicin.

\section{Discussion}

Chemical analysis of $C$. anisata oil showed that methyl eugenol and estragole are the most abundant compounds in this study. The oil extracted by HD method yielded clearer and more chemical compounds than oil extracted by solvent-free microwave extraction method. This agrees with Cook and Lanaras (2016) who noted the high yields and good recovery constituents of essential oils extracted by HD method. Several compounds of Clausena (C. dentata, C. dimidata, C. engleri and C. indica), similar to this study, have been reported in which the major compounds are estragole (Ekundayo, Oguntimein \& Hammerschmidt 1986) 
TABLE 1: Chemical composition of essential oil of $C$. anisata obtained by solvent-free extraction and hydrodistillation.

\begin{tabular}{|c|c|c|c|c|c|c|c|}
\hline \multirow[t]{2}{*}{ No. } & \multirow[t]{2}{*}{ Chemical compounds } & \multicolumn{2}{|c|}{$\mathrm{RT} / \mathrm{min}$} & \multicolumn{2}{|c|}{ SFME } & \multicolumn{2}{|c|}{ HD } \\
\hline & & SFME & HD & Area $\%$ & KI Values & Area $\%$ & KI Values \\
\hline 1 & Alpha-pinene $\dagger$ & 5.70 & 5.70 & 0.34 & 1026 & 0.56 & 1026 \\
\hline 2 & Limonene $\dagger$ & 7.74 & 7.90 & 0.71 & 1128 & 10.99 & 1135 \\
\hline 3 & 1,8-Cineole $\dagger$ & 7.82 & 8.12 & 0.23 & 1132 & 0.68 & 1147 \\
\hline 4 & (-)-Bornyl acetate $\dagger$ & 13.70 & 13.75 & 0.69 & 1368 & 0.46 & 1346 \\
\hline 5 & Methyl eugenol $\dagger$ & 16.75 & 13.75 & 76.60 & 1507 & 36.04 & 1507 \\
\hline 6 & Germacrene- $D^{\dagger}$ & 18.10 & 18.38 & 0.34 & 1551 & 2.08 & 1563 \\
\hline 7 & Cis-methyl isoeugenol $\dagger$ & 18.28 & 18.28 & 0.77 & 1572 & 0.70 & 1552 \\
\hline 8 & (+) Spathulenol $\dagger$ & 20.00 & 20.00 & 0.18 & 1632 & 0.84 & 1639 \\
\hline 9 & Methyl chavicol (Estragole) & 11.83 & 12.04 & 14.48 & 1332 & - & - \\
\hline 10 & Beta-pinene & 6.62 & - & 0.11 & 1072 & - & - \\
\hline 11 & Myrcene & 6.80 & - & 0.45 & 1081 & - & - \\
\hline 12 & Linalyl acetate & 9.34 & - & 0.53 & 1192 & - & - \\
\hline 13 & P-Mentha-2, 8-dien-1-ol, trans-(.+-.)- & 9.90 & - & 0.13 & 1235 & - & - \\
\hline 14 & 2,3-epoxygeranial & 10.25 & - & 0.17 & 1253 & - & - \\
\hline 15 & Camphor & 10.53 & - & 0.62 & 1267 & - & - \\
\hline 16 & 2,6-Dimethyl-1,5,7-octatrien-3-ol & 10.68 & - & 0.40 & 1274 & - & - \\
\hline 17 & Borneol L & 11.12 & - & 0.23 & 1296 & - & - \\
\hline 18 & Verbenon & 12.01 & - & 0.81 & 1340 & - & - \\
\hline 19 & Cis-Citral & 12.61 & - & 0.27 & 1370 & - & - \\
\hline 20 & Geranial & 13.29 & - & 0.51 & 1404 & - & - \\
\hline 21 & 2-Undecanone & 13.84 & - & 0.44 & 1383 & - & - \\
\hline 22 & Triphenylphosphine oxide & 32.58 & - & 1.00 & 2246 & - & - \\
\hline 23 & 4-Allyl anisole (Estragole) & - & 12.04 & - & - & 26.43 & 1342 \\
\hline 24 & Beta-myrcene & - & 6.92 & - & - & 8.28 & 1087 \\
\hline 25 & (+)-3-Carene & - & 7.31 & - & - & 0.62 & 1106 \\
\hline 26 & Nonanal (n-nonylaldehyde) & - & 9.44 & - & - & 0.64 & 1287 \\
\hline 27 & L-camphor & - & 10.52 & - & - & 0.15 & 1266 \\
\hline 28 & Citronellal & - & 10.56 & - & - & 0.31 & 1269 \\
\hline 29 & Cyclopropane, methylmethylene- & - & 10.66 & - & - & 0.58 & - \\
\hline 30 & 4-Allyl anisole (Estragole) & - & 12.04 & - & - & 26.43 & 1342 \\
\hline 31 & P-allylAnisole & - & 12.12 & - & - & 0.46 & 1346 \\
\hline 32 & Beta.-sesquiphellandrene & - & 17.75 & - & - & 0.19 & 1536 \\
\hline 33 & Beta.-cubebene & - & 18.32 & - & - & 1.15 & 1560 \\
\hline 34 & Trans-methyl isoeugenol & - & 18.52 & - & - & 1.97 & 1582 \\
\hline 35 & Bicyclogermacrene & - & 18.61 & - & - & 0.45 & 1573 \\
\hline 36 & Beta.-bisabolene & - & 18.75 & - & - & 0.13 & 1579 \\
\hline 37 & Delta.-Cadinene & - & 18.93 & - & - & 0.18 & 1587 \\
\hline 38 & Beta.-sesquiphellandrene & - & 19.05 & - & - & 0.11 & 1592 \\
\hline 39 & $\begin{array}{l}\text { 1-Formyl-2,2,6-trimthyl-3-cis-(3- } \\
\text { methyl-2-butne-1-yl)5-cyclohexene }\end{array}$ & - & 19.33 & - & - & 0.07 & - \\
\hline 40 & 4-Mercaptotoluene ( $p$-thiocresol) & - & 19.69 & - & - & 0.14 & - \\
\hline 41 & Germacrene B & - & 19.79 & - & - & 0.73 & 1624 \\
\hline 42 & 2,3-Dibromo-8-phenyl-p-menthane & - & 20.06 & - & - & 0.19 & 1634 \\
\hline 43 & Oplopenone.Beta.-oplopenone & - & 20.21 & - & - & 0.14 & 1642 \\
\hline 44 & Caryophyllene oxide & - & 20.25 & - & - & 0.22 & 1643 \\
\hline 45 & Zingiberenol & - & 20.30 & - & - & 0.19 & - \\
\hline 46 & Salvial-4(14)-en-1-one & - & 20.44 & - & - & 0.14 & - \\
\hline 47 & (+)-.Alpha.-longipinene & - & 21.06 & - & - & 0.34 & 1678 \\
\hline 48 & Aromadendrene & - & 21.16 & - & - & 0.25 & 1683 \\
\hline 49 & Salvial-4(14)-en-1-one & - & 21.38 & - & - & 0.12 & - \\
\hline 50 & $\begin{array}{l}\text { T-muurolol (1-naphthalenol, } \\
\text { 1,2,3,4,4a,7,8,8a-octahydro-1,6- } \\
\text { dimethyl-4-(1-methylethyl)-) }\end{array}$ & - & 21.55 & - & - & 0.42 & 1700 \\
\hline 51 & $\begin{array}{l}\text { 1H-indole-3-carboxylic acid, } \\
\text { 4-hydroxy- (4-hydroxyindole-3- } \\
\text { carboxylic acid) }\end{array}$ & - & 21.64 & - & - & 0.20 & - \\
\hline
\end{tabular}

$\mathrm{KI}$, Kovats index; RT, retention time; HD, hydrodistilled; SFME, solvent-free microwaved essential.

$\dagger$, compound found in oil from both extraction methods. 


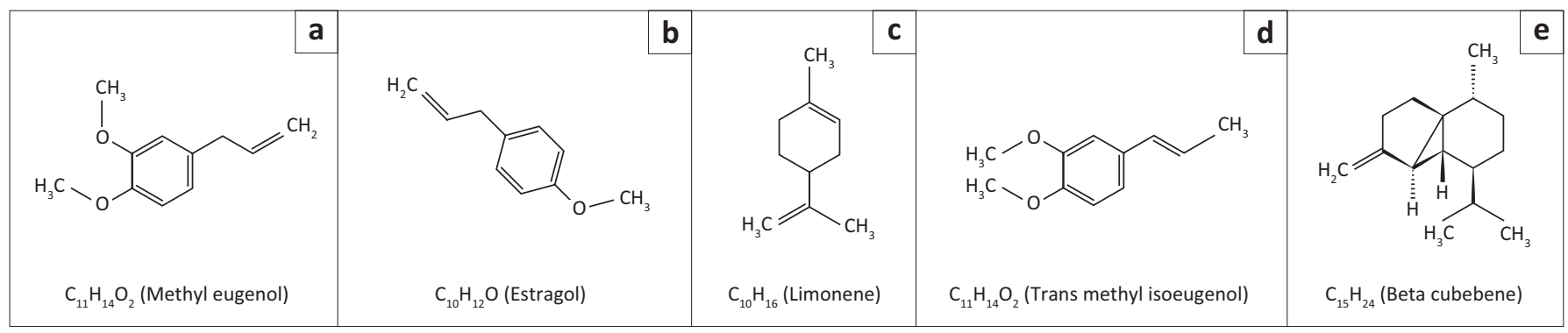

FIGURE 1: Chemical structures of some monoterpenoids and sequiterpenoids identified with high percentages in the essential oil of $C$. anisata obtained by hydrodistillation and solvent-free microwave extraction by using gas chromatography-mass spectroscopy analysis.

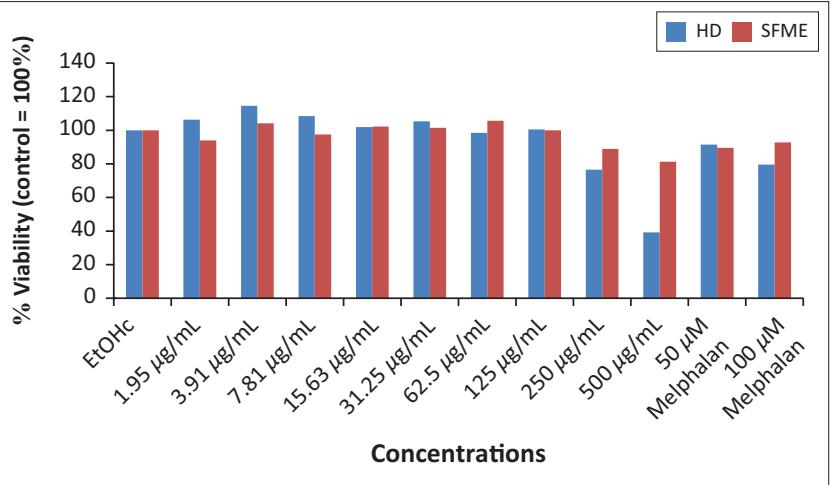

$\mathrm{HD}$, hydrodistilled; SFME, solvent-free microwaved essential; EtOHc, ethanol control.

FIGURE 2: Cytotoxicity effects of volatile oil obtained by solvent-free microwave extraction and hydrodistillation against the human dermal fibroblast cell line.

and $\beta$-pinene (Senthilkumar \& Venkatesalu 2009). Methyl eugenol is a major compound extracted through HD and SFME in this study at $36.04 \%$ and $76.60 \%$ respectively, but identified in trace amount $(0.3 \%)$ in the leaf essential oils of C. engleri from Vietnam (Trung et al. 2014). Volatile oil of C. anisata extracted from $\mathrm{HD}$ in this study revealed $\beta$-myrcene at $8.28 \%$, whilst Zhou et al. (2008) observed that a steam-distilled oil of $C$. dentata from China exhibited $\beta$-myrcene (51.5\%) as its main compound, and constituents of the water-distilled oil of C. indica of Chinese origin comprised $\beta$-myrcene at $5.03 \%$. Trung et al. (2014) identified the same compound in the leaf essential oils of $C$. dentata, $C$. dimidata and C. indica at $14.3 \%, 1.4 \%$ and $3.3 \%$, respectively. Another report (Zhou et al. 2008) identified $\beta$-myrcene $(23.46 \%$ and $0.1 \%)$ as the compounds in the fruit and leaf oils of $C$. indica, respectively. Furthermore, in this study, $\alpha$-pinene composition is observed in trace amount to be $0.56 \%$ and $0.34 \%$ in HD and SFME respectively but in substantial amount (21.7\%) in C. dentata (Trung et al. 2014). The observation in this study is in agreement with the previous report on C. anisata from different geographical regions in the south of Croatia (Jekovic \& Mastelic 2001).

Cell viability and/or proliferation rates of cells are good indication of cell health (Aslantürk 2018). In this study, the $\mathrm{IC}_{50}$ values of $\mathrm{C}$. anisata essential oils extracted by SFME and HD methods were $1216 \mu \mathrm{g} / \mathrm{mL}$ and $383 \mu \mathrm{g} / \mathrm{mL}$, respectively. Extracts that demonstrate an $\mathrm{LC}_{50}$ value greater than $100 \mu \mathrm{g} / \mathrm{mL}$ were considered as non-toxic, and an $\mathrm{LC}_{50}$ value less than $100 \mu \mathrm{g} / \mathrm{mL}$ as toxic (Meyer et al. 1982).
Therefore, C. anisata is considered safe for consumption. However, from the findings of Makirita, Chauka and Chacha (2016), C. anisata leaf chloroform and C. anisata twigs ethyl acetate extracts, which demonstrated an $\mathrm{LC}_{50}$ value of $3.5761 \mu \mathrm{g} / \mathrm{mL}$ and $6.1276 \mu \mathrm{g} / \mathrm{mL}$ respectively, were much more cytotoxic and described as having anticancer prospects according to Meyer et al. (1982) who pointed out that extracts with an $\mathrm{LC}_{50}$ value less than $20 \mu \mathrm{g} / \mathrm{mL}$ are reckoned as potential anticancer agents.

The in vitro antitubercular activity evaluated against M. tuberculosis showed that C. anisata volatile oils and EMB have no antimycobacterial effect against $M$. tuberculosis strain. This observation supported the report of York, Van Vuuren and De Wet (2012) that aqueous and organic extract of C. anisata leaf is inactive against $M$. smegmatis but in contrast to Gizachew, Mirutse and Tilahun (2013) who reported that $\mathrm{MeOH}$ and aqueous extracts of $C$. anisata leaf growing in Ethiopia showed promising growth inhibition on Mycobacterium bovis (SB 1176). The result of this study support the report that geographical location of plants influences its chemical composition and its bioactivity (Jekovic \& Mastelic 2001). The medicinal plant bioactivity depends on the chemical constituents. This may be responsible for the resistance of $M$. tuberculosis strain to the oils. This specific strain of M. tuberculosis might also be resistant to EMB. The low activity recorded by the oil and EMB could be because of strong resistance developed by $M$. tuberculosis.

\section{Conclusion}

This study showed that $C$. anisata, having methyl eugenol and estragole in abundance, is safe for consumption considering its various therapeutic uses; however, no remarkable antimycobacterial activity was recorded on the oil of the plant. The HD yielded purer and more chemical compounds than solvent-free microwave extraction. Combinative potent oils by HD method can be considered for synergetic and enhanced effect against $M$. tuberculosis. Further studies in this regard are strongly recommended.

\section{Acknowledgements}

The author thanks Mr Temitope Omogbene, Research Assistant, Biomedicinal Research Centre, Forestry Research Institute of Nigeria for his contribution and also scholars and 
Research Professor of Medicinal Plant and Economic Development, Niche area, Department of Botany, Univeristy of Fort Hare for their immense contributions towards achieving this scholarly research work.

\section{Competing interests}

The author has declared that no competing interests exist.

\section{Authors' contributions}

I.O.L. designed the study, coordinated plant material collection, carried out all the experiments and drafted the manuscript.

\section{Funding information}

This study was supported by Govan Mbeki Research and Development Centre of University of Fort Hare, South Africa.

\section{Data availability statement}

Data sharing is not applicable to this article as no new data were created or analysed in this study.

\section{Disclaimer}

The views and opinions expressed in this article are those of the authors and do not necessarily reflect the official policy or position of any affiliated agency of the authors.

\section{References}

Aslanturk, O, 2018, In Vitro Cytotoxicity and Cell Viability Assays: Principles, Advantages, and Disadvantages, in M.L. Larramendy, and S. Solonesk, (Eds.) Genotoxicity - A Predictable Risk to Our Actual World, IntechOpen, London. https://doi.org/10.5772/intechopen.71923

British Pharmacopoeia, 1980, pp. 109-110, Her Majesty's Stationery Office, Journa of Pharmaceutical Sciences 69(11), Page 1362. https://doi.org/10.1002/ jps.2600691142

Centers for Disease Control and Prevention (CDC), 2016, Treatment for TB disease. Tuberculosis (TB), viewed 02 May 2016, from https://www.cdc.gov/tb/topic/ treatment/tbdisease.htm.

Centers for Disease Control and Prevention (CDC), 2020, Coronavirus Disease (COVID-19); How it spreads, viewed 01 May 2020, from https://www.cdc.gov/ coronavirus/2019-ncov/prevent-getting-sick/how-covid-spreads.html.

Cook, C.M. \& Lanaras, T., 2016, 'Essential oils: Isolation, production and uses', in Encyclopedia of food and health, pp. 552-557.

Dry DIST, 2004, Milestone srl, Via Fratebenefratelli, 1/5, I-24010 Sorisole, Bergamo, Italy, viewed from March 23, 2017. www.milestonesrl.com.

Ekundayo, O., Oguntimein, B.O. \& Hammerschmidt, F.J., 1986, 'Composition of essential oil of Anonna Senegalensis Var Senegalensis', Planta Medica 52(3), 202-204. https://doi.org/10.1055/s-2007-969122

Franzblau, S.G., Witzig, R.S., McLaughlin, J.C., Torres, P., Madico, G., Hernandez, A. et al., 1998, 'Rapid, low-technology MIC determination witk clinical Mycobacterium tuberculosis isolates by using the microplate alamar blue assay', Journal of Clinical Microbiology 36(2), 362-366. https://doi.org/10.1128/JCM.36.2.362-366.1998

Gizachew, Y.E., Mirutse, G. \& Tilahun, T., 2013, 'Antimycobacterial activities of selected Ethiopian traditional medicinal plants used for treatment of symptoms of tuberculosis', Global Advanced Research Journal of Medicinal Plants (GARJMP) 2(2), 22-29.
Grierson, D.S. \& Afolayan, A.J., 1999, 'An ethnobotanicalstudy of plants used for the treatment of wounds in the Eastern Cape, South Africa', Journal of Ethnopharmacology 67(3), 327-332.

Hamza, O.J., Van den Bout-Van den Beukel, C.J. \& Matee, M.l., 2006, 'Antifungal activity of some Tanzanian plants for the treatment of fungal infections', Journal of Ethnopharmacology 108(1), 124-132. https://doi.org/10.1016/j.jep.2006.04.026

Holst-Hansen, C. \& Brünnner, N., 1998, 'MTT-cell proliferation assay', in J.E. Celis (ed.), Cell Biology: A Laboratory Handbook, pp. 16-18, 2nd edn., Academic Press, San Diego, CA.

Ibekwe, N.N. \& Ameh, S.J., 2015, 'Plant natural products research in tuberculosis drug discovery and development: A situation report with focus on Nigerian biodiversity', African Journal of Biotechnology 13(23), 2307-2320. https://doi.org/10.5897/ AJB2013.13491

Jekovic, I. \& Mastelic, J., 2001, 'The impact of both the season of collection and drying of the volatile constituents of Origanum vulgare spp Hirtum grown wild in
Croatia', International Journal of Food Science Technology 36(6), 649-654.

Lawal, I.O., Grierson, D.S. \& Afolayan, A.J., 2014, 'Phytotherapeutic information on plants used for the treatment of tuberculosis in Eastern Cape Province, South Africa', Evidence-Based Complementary and Alternative Medicine, Article ID 735423, 11 pages, 2014. https://doi.org/10.1155/2014/735423

Makirita, W.E., Chauka, L.J. \& Chacha, M., 2016, 'Antimicrobial and cytotoxicity activity of Clausena anisata, Acokanthera shemperii and Olea europaea growing in Tanzania', European Journal of Medicinal Plants 14(2), 1-9. https://doi. org/10.9734/EJMP/2016/23635

Meyer, B.N., Ferrigni, N.R., Putnam, J.E., Jacobsen, L.B., Nichols, D.E., Nicols, J.L. et al. 1982, 'Brine shrimp: A convenient general bioassay for active plant constituents', Planta Medica 45(5), 31-34. https://doi.org/10.1055/s-2007-971236

Okoh, O.O., Sadimenko, A.P. \& Afolayan, A.J., 2010, 'Comparative evaluation of the antibacterial activities of the essential oils of Rosmarinus officinalis L. obtained by hydrodistillation and solvent free microwave extraction methods', Food Chemistry 120(1), 308-312. https://doi.org/10.1016/j.foodchem.2009.09.084

Omoruyi, B.E., Anthony, A.J. \& Bradley, G., 2014, 'Chemical composition profiling and antifungal activity of the essential oil and plant extracts of Mesembryanthemum edule (L.) Bolus leaves', African Journal of Traditional Complementary and Alternative Medicine 11(4), 19-30. https://doi.org/10.4314/ajtcam.v11i4.4

Payan, F.R., Leite, C.Q.F., Coelho, R.G., Coutinho, I.D., Honda, N.K., Cardoso, C.A.L. et al., 2009, 'Evaluation of anti-Mycobacterium tuberculosis activity of Campomanesia adamantium (Myrtaceae)', Química Nova 32(5), 1222-1226. https://doi.org/10.1590/S010040422009000500026

Senthilkumar, A. \& Venkatesalu, V., 2009, 'Phytochemical analysis and antibacterial activity of the essential oil of Clausena anisata (Willd.) hook. f. ex benth. Int', Journal of Integrative Biology 5(2), 116-120.

Shehzad, A., Rehman, G., UI-Islam, M., Khattak, W.A. \& Lee, Y.S., 2013, 'Challenges in the development of drugs for the treatment of tuberculosis', Brazilian Journal of Infectious Diseases 17(1), 74-81, https://doi.org/10.1016/j.bjid.2012.10.009

TB Statistics South Africa, 2015, TB Statistics for South Africa - National \& provincial. TBFACTS.ORG, United Kingdom.

Teleuti, A., Philipp, W.J., Sreevatsan, S., Bernasconi, C., Stockbauer, K.E., Wieles, B. et al., 1997, 'The emb operon, a gene cluster of Mycobacterium tuberculosis involved in resistance to ethambutol', Nature Medicine 3(5), 567-570. https://doi. org/10.1038/nm0597-567

Trung, H., Thang, T., Ban, P., Hoi, T., Dai, D. \& Ogunwande, I., 2014, 'Terpene constituents of the leaves of five Vietnamese species of Clausena (Rutaceae)', Natural Product Research 28(9), 622-630. https://doi.org/10.1080/14786419.2014.888555

Van Wyk, B.E. \& Gericke, N., 2000, Peoples plants, Briza Publications, Pretoria.

Van Wyk, B.E., Van Oudtshoorn, B. \& Gericke, N., 2002, Medicinal plants of South Africa, 2nd edn., pp. 156-157, Briza Publications, Pretoria.

World Health Organization, 2012, Tuberculosis, World Health Organization, Geneva, Fact Sheet No 104, pp. 1-2.

World Health Organization, 2015, Use of high burden country lists for TB by WHO in the post-2015 era, World Health Organization, Geneva, Contract No.: WHO/HTM/ TB/2015.29.

World Health Organization, 2017, Global tuberculosis report 2017, World Health Organization, Geneva, Licence: CC BY-NCSA 3.0 IGO.

World Health Organization, 2018, What is TB? How is it treated?, World Health Organization, viewed 02 May 2020, from https://www.who.int/news-room/q-adetail/what-is-tb-how-is-it-treated.

York T., Van Vuuren S.F. \& De Wet, H., 2012, 'An antimicrobial evaluation of plants used for the treatment of respiratory infections in rural Maputaland, KwaZulu-Natal, South Africa', J. Ethnopharmacol. 144(1), 118-127. https://doi.org/10.1016/j. jep.2012.08.038

Zhou, H., Ke-Jian, H., Zhi-Wen, P., Cui-Wu, L., Guan, H. \& Tao, S., 2008, 'Headspace solid phase microextraction-gas chromatography-mass spectrometry for analysis of volatile components from the fresh leaves and the fresh fruit peel of Clausena indica (Datz.) Oliv.', Acta Scientifik Natura Universite Sunyatseni 47, 71-74. 


\section{APPENDIX 1}

\section{Antimycobacterium activity on 96-well microtitre plate}

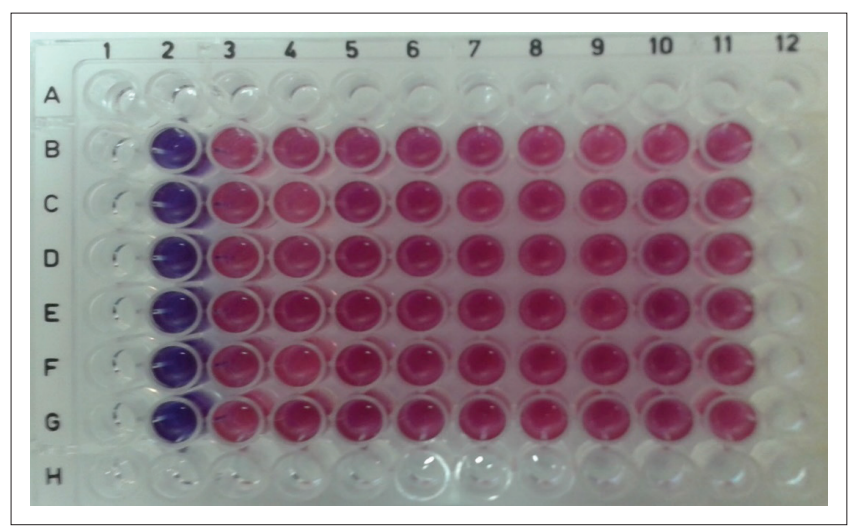

FIGURE 1-A1: Plate A.1 - Inactivity effect of volatile oils from solvent-free microwaved essential and hydrodistilled on Mycobacterium tuberculosis on a 96-well microtitre plate showing: Well A1-12; $\mathrm{H} 1-12$ : Sterile water; well 2 (Control 1): $100 \mu \mathrm{L}$ medium and $100 \mu \mathrm{L}$ of $500 \mu \mathrm{g} / \mathrm{mL}$ volatile oil; no Mycobacterium tuberculosis; well 3 (Control 2): $100 \mu \mathrm{L}$ medium and $100 \mu \mathrm{L}$ Mycobacterium tuberculosis inoculums; well 4 (Control 3): $100 \mu \mathrm{L}$ medium containing $1 \%$ absolute ethanol and $100 \mu \mathrm{L}$ Mycobacterium tuberculosis inoculum; wells $5-11$ : $(250,125,67.5,31.3,15.6,7.8,3.9 \mu \mathrm{g} / \mathrm{mL}) ; \mathrm{B}, \mathrm{C}$, D: oil from solvent-free microwaved essential and E, F, G: oil from hydrodistilled.

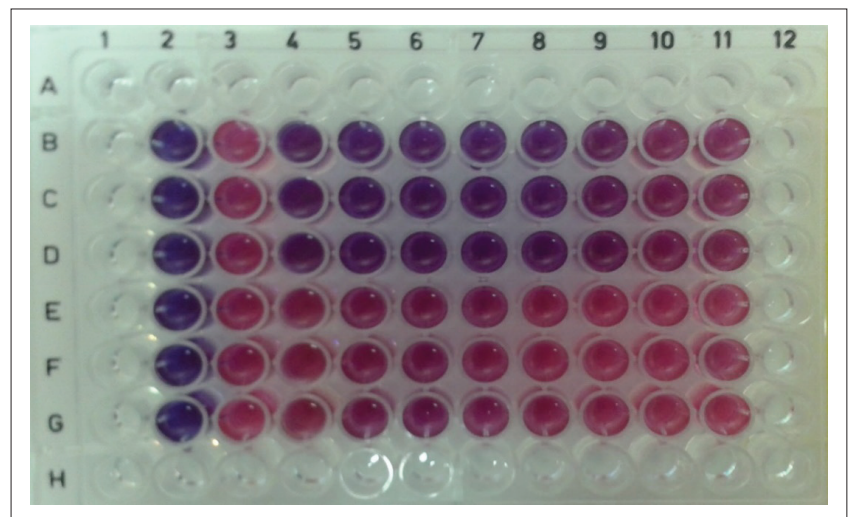

FIGURE 2-A1: Plate A.2 - Susceptibility effect of rifampicin and weak inhibitory effect of Ethambutol on Mycobacterium tuberculosis on a 96-well microtitre plate: Well A1-12; H1-12: Sterile water; well 2 (Control 1): $100 \mu \mathrm{L}$ medium and $100 \mu \mathrm{L}$ of $500 \mu \mathrm{g} / \mathrm{mL}$ volatile oil; no Mycobacterium tuberculosis; well 3 (Control 2): $100 \mu \mathrm{L}$ medium and $100 \mu \mathrm{L}$ Mycobacterium tuberculosis inoculums; well 4 (Control 3): $100 \mu \mathrm{L}$ medium containing $1 \%$ absolute ethanol and $100 \mu \mathrm{L}$ Mycobacterium tuberculosis inoculum; wells 5-11: (250, 125, 67.5, 31.3, 15.6 7.8, $3.9 \mu \mathrm{g} / \mathrm{mL}$ ); B, C, D: oil from solvent-free microwaved essential and E, F, G: oil from hydrodistilled. 